\title{
Osteomiyelitin patofizyolojisi
}

\author{
Pathophysiology of osteomyelitis
}

\author{
Gizem Issın \\ Erzincan Binali Yıldırım Üniversitesi, Mengücek Gazi Eğitim ve Araştırma Hastanesi, Patoloji Servisi, Erzincan
}

Osteomiyelit uzun tedavi süreci ve ortaya çıkan ciddi komplikasyonlar nedeniyle ortopedi ve travmatoloji uzmanlarının karşılaştığı en önemli enfeksiyon hastalıklarından biridir. Etkili bir tedavi planı oluşturulmasında klinik, radyolojik ve laboratuvar verilerinin birlikte değerlendirilmesi gerekir. Bu derlemede ostemiyelitin patogenezi, histolojik bulguları ve bulguların klinik yansımalarına değinilmiştir.

Anahtar sözcülkler: osteomiyelit; kemik enfeksiyonu; akut hematojenöz osteomiyelit; protez enfeksiyonu
Osteomyelitis is one of the most important infectious diseases faced by orthopaedics and traumatology specialists with long treatment processes and serious complications. Clinical, radiological, and laboratory data should be evaluated together to establish an effective treatment plan. In this review, the pathogenesis, histological findings, and clinical reflections of osteomyelitis are discussed.

Key words: osteomyelitis; bone infection; acute hematogenous osteomyelitis; joint replacement infection

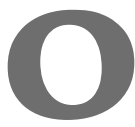

steomiyelit kelimesi Antik Yunanca'da 'kemik' anlamına gelen 'osteon', 'ilik' anlamına gelen 'myelos' ve 'enflamasyon' anlamına gelen 'itis' kelimelerinden oluşmakta, kabaca kemik ve kemik iliğinin enflamasyonu anlamına gelmektedir. Osteomiyelit; bakteriler başta olmak üzere mikobakteriler veya mantarlar gibi patojen mikroorganizmaların neden olduğu, kemikte yıkım ve nekroza yol açabilen, ilerleyici veya tedavi süreci zor olan enflamatuar bir kemik hastalığıdır. ${ }^{[1]}$

Bilinen en eski osteomiyelit olgusunun izine, 291 ila 250 milyon yıl önce yaşamış dimetrodon Permiyen sürüngeninin kırık omurgasında rastlanmıştır. ${ }^{[2]}$ Tarih kadar eski olan bu kadim hastalık, Hipokrat döneminde kemik kırı̆ğı sonrası gelişen sinsi ve inatçı enfeksiyon olarak tanımlanmaktaydı. 'Osteomiyelit' terimi ise ilk kez 1844 yılında Fransız cerrah Auguste Nélaton tarafından kullanılmıştır. ${ }^{[3]}$ Penisilinin keşfinden önceki dönemde ostemiyelit; mortalite oranı yüksek, genellikle sekel bırakan dermansız bir hastalık olarak bilinir, tedavisi için hastalıklı dokuların cerrahi olarak çıkarılması önerilirdi. ${ }^{[4]} 1941$ yılında penisilinin keşfi ve enfeksiyon hastalıklarının tedavisinde kullanılmaya başlanması ile osteomiyelitin tedavisinde yeni bir sayfa açılmış oldu..$^{[5]}$ Erken tanı ve hızlı başlanan penisilin tedavisi sayesinde hastalığın mortalite ve sekel bırakma oranlarında düşüş izlenmiştir. Ancak bu başarı antibiyotiğe dirençli suşların gelişimi ile sekteye uğramıştır. Ostemiyelitlerin \%80'inden fazlasına neden olan Staphylococcus aureus (S.aureus) son derece değişken ve hızla antibiyotik direnci geliştiren patojen bir bakteridir. ${ }^{[6]}$ Bakterinin sahip olduğu virulans faktörleri osteomiyelit tedavisini zorlaştırmakta, cerrahi alan debridmanı ve uzun süreli antimikrobiyal tedaviye rağmen, enfeksiyonlar tekrarlamaya devam etmektedir. Cerrahi teknikler ve antibiyoterapi rejimleri sayesinde yıllar içerisinde hastalığa bağlı mortalite ve sekel bırakma oranlarında azalma izlense bile, bugün hâlâ osteomiyelit tedavi süreci zorlu ve hatta tedavisi mezarda biten bir hastalık olarak görülmeye devam etmektedir.

Osteomiyelitin klinik prezentasyonu ve tedavisi; enfeksiyona neden olan mikroorganizmaya, hastanın genel sağlık durumuna, tutulan kemik alanına ve enfeksiyonun yayılım şekline göre farklılıklar gösterebilir. Osteomiyelitte uygun tedavi planını oluşturabilmek için, hastanın klinik özelliklerinin, radyolojik, laboratuvar ve patolojik bulgularla korele edildiği bütüncül bir yaklaşım izlemek gerekir. Bu derlemede osteomiyelitin patofizyolojisine, histolojik bulgularına ve bu bulguların klinik yansımalarına değinilmiştir.

- Illetişim adresi: Uzm. Dr. Gizem Issın, Erzincan Binali Yıldırım Üniversitesi, Mengücek Gazi Eğitim ve Araştırma Hastanesi, Erzincan Tel: 0532 - 4579220 e-posta: gizemisin@gmail.com

- Geliș tarihi: 26 Mayıs $2020 \quad$ Kabul tarihi: 12 Temmuz 2020 


\section{EPIDEMIYOLOJi}

Osteomiyelit insidansının, çocuklarda yılda 100.000 çocuk başına 2-13 olgu, erişkinlerde ise 100.000 hasta başına $13-21,8$ olgu olduğu tahmin edilmektedir. ${ }^{[6-8]}$ Sosyoekonomik olarak az gelişmiş bölgelerde, immunosupresyon ve yetersiz beslenme gibi predispozan faktörlere ve yüksek travma insidansına da bağlı olarak prevalansta artış izlenebilmektedir. ${ }^{[9]}$ Osteomiyelit her yaş grubunda görülebilmekle birlikte, insidansı belirli yaş gruplarında artış gösterir. Çocukluk çağında hastalığın pik insidansı 1 yaş altıdır. Bunun yanında genellikle, mikrotravmanın sık yaşandığı beş yaşın altındaki çocuklarda ve hızlı kemik büyümesinin izlendiği 9-13 yaş grubu çocuklarda görülür. Görülme oranı her yaş grubunda, kadınlara kıyasla erkeklerde daha fazladır. Çocuklarda en sık alt ve üst ekstremitenin uzun kemiklerinde tutulum izlenir. Bunu pelvis, ayak kemikleri ve vertabra tutulumu takip eder. ${ }^{[7,8]}$ Hastaların çoğunda enfeksiyon genellikle tek kemikte izlenmekle birlikte, bebeklerin \%7'sinde, yenidoğanların ise \%22'sinde birden fazla kemikte tutulum izlendiği bildirilmiştir. ${ }^{[10]}$

Erişkinlerde ise en sık 57-70 yaş aralığında görülür. Çocukluk çağına benzer şekilde hastaların çoğunluğunu erkekler oluşturmaktadır. Erişkin çağında en sık metatarsal ve ayak parmaklarında tutulum izlenir. Bunu alt ekstremitenin uzun kemikleri, omurga, sternum ve pelvis tutulumu izler. Enfeksiyon genelikle tek odakta izlenmekle birlikte, olguların \%6'sında birden fazla kemikte tutulum izlendiği bildirilmiştir. ${ }^{[8]}$

Osteomiyelit insidansının yıllar içerisinde, çocuklar ve elli yaşından küçük yetişkinler arasında nispeten sabit kaldığı, elli yaş üzerinde ise üç kata yakın artış gösterdiği bildirilmiştir. Bu artıştaki en büyük etken, diyabetes mellituslu hastalardır. Bu hastaların daha uzun yaşaması nedeniyle nöropati ve vasküler yetmezlik ile ilişkili yumuşak doku kaybına binaen gelişen osteomiyelit olgularında artış izlenmiştir. Bir diğer etken ise protez presedürleri için artan cerrahi girişim oranları ve yaban$\mathrm{Cl}$ cisime bağlı gelişen osteomiyelitlerdeki artıştır. ${ }^{[8]}$

\section{ETYOLOji}

Osteomiyelite, bakteriler, virüsler, parazitler veya mantarlar gibi birçok mikroorganizma neden olabilse de, enfeksiyona yol açan etken sıklıkla piyojenik bakteriler ve mikobakterilerdir. Hastalığa neden olan mikroorganizma diyabet, orak hücre anemisi, intravenöz ilaç kullanımı veya immun yetmezlik gibi spesifik risk faktörlerine ve yaşa göre değişiklik gösterebilmektedir (Tablo 1). ${ }^{[11]}$

Tüm yaş gruplarında osteomiyelit olgularının, $\% 80$ ila \%90'ından, cilt ve mukoza başta olmak üzere birçok vücut bölgesinde flora üyesi olarak bulunan S.aureus sorumludur. ${ }^{[6]}$ Yenidoğanlarda bunu, B grubu streptokoklar ve gram negatif enterik basiller takip ederken, beş yaş altı çocuk yaş grubunda ise; A grubu streptokoklar, Haemophilus influenzae Tip b, Kingella kingae takip etmektedir. Streptococcus pneumonia ve Haemophilus influenzae Tip b'nin çocukluk çağı aşılama programlarına dâhil edilmesinden bu yana, bu etkenlere bağlı osteomiyelit gelişim oranlarında belirgin düşüş izlenmiştir. Orak hücre anemisi olan çocuklarda, osteoartiküler enfeksiyonlara sıklıkla S.aureus ve Salmonella türleri neden olurken, intravenöz ilaç kullanımı olan hastalarda Pseudomonas aeruginosa (P.aeruginosa) en sık izole edilen etkenlerden biridir. ${ }^{[12]}$

Erişkinlerde ise S.aureus ve bir diğer cilt florası üyesi olan Staphylococcus epidermidis ortopedik donanım implantları

Tablo 1. Yaşa ve predispozan faktörlere göre osteomiyelitlerde en sık izole edilen etken mikroorganizmalar ${ }^{[11]}$

\begin{tabular}{ll}
\hline Yaş grubu & En sık izole edilen etken mikroorganizmalar \\
\hline Yenidoğan & S.aureus, enterobakterler, A ve B grubu steptokoklar \\
Çocukluk çağı & S.aureus, enterobakterler, B grubu steptokoklar, Haemophilus influenzae Tip b \\
Erişkin & S.aureus \\
\hline Predispozan faktörler & En sık izole edilen etken mikroorganizmalar \\
\hline İntravenöz ilaç kullanımı & S.aureus, P.aeruginosa, Serratia marcescens, Kandida türleri \\
İmmun yetmezlik durumları & S.aureus, Bartonella henselae, Aspergillus, Mikobakterler, Candida albicans \\
Üriner enfeksiyon & P.aeruginosa, enterobakterler \\
Fiksatör, implantlar & S.aureus, koagülaz negatif stafilokoklar \\
Diyabet, vasküler yetmezlik, açık kırık & Polimikrobiyal: S.aureus, koagülaz negatif stafilokoklar, streptokoklar, enterokoklar, \\
& Gram negatif anaerop basiller
\end{tabular}


gibi yabancı cisim varlığında gelişen osteomiyelitlerde en sık izole edilen etkenlerdir. Bunu P.aeruginosa ve enterokoklar takip eder. Enfeksiyonların çoğunluğundan tek mikroorganizma sorumlu olmakla birlikte, son yıllarda gram-negatif bakterilerin neden olduğu polimikrobiyal enfeksiyon oranlarında artış olduğunu bildirmiştir. ${ }^{[13]}$

Mikobakterilere bağlı gelişen enfeksiyonlarda ise başlıca etken Mycobacterium tuberculosis'tir. Mikroorganizmalar sıklıkla visseral hastalık odağından komşuluk yoluyla, nadiren de hematojen-lenfatik dolaşım ile yayılır. Mikobakterlere bağlı gelişen enfeksiyonlar sıklıkla vertebrada karşımıza çıkmaktadır. Bunu kalça ve diz bölgesi tutulumu takip eder. Hastalık genellikle tek bir odakta izlenmekle birlikte, immun sistemi baskılanmış çocuklar ve yetişkinlerde, multifokal kemik tutulumu izlenebilir. ${ }^{[14]}$

Candida türleri, Blastomyces dermatitidis, Coccioides immitus, Histoplasma capsulatum ve Cryptococcus neoformans gibi fungal mikroorganizmalar pulmoner veya sistemik enfeksiyon odağından hematojen yayılım ile enfeksiyona neden olan mantar türleridir. Aspergillus türleri, Sporothrix schenckii ve Mycetoma'lar ise öncelikle yumuşak doku enfeksiyonu oluşturarak komşuluk yoluyla kemik dokuya erişerek enfeksiyona yol açar. ${ }^{[15]}$ Helmitik osteomiyelit ise oldukça nadirdir ve bildirilen tek etken Echinococcus granulosa'dır. ${ }^{[16]}$

\section{OSTEOMIYELIT PATOGENEZI VE HISTOLOJIK BULGULARI}

Osteomiyelit, ortaya çıkış mekanizması, tutulum alanı ve hastalık süresi göz önüne alındığında, hastadan hastaya farklı bulgular ile seyreden, heterojen bir grup hastalık topluluğudur. Patojen mikroorganizmanın kaynağına ve hastalığın oluşum mekanizmasına göre; hematojen yayılım ile oluşan osteomiyelit, kutanöz ülser veya derin yumuşak doku apsesi gibi komşu enfeksiyonun yayılımı ile oluşan osteomiyelit, travma ya da cerrahi işlemler sonrasında, doğrudan kemik içerisine mikroorganizmaların ekimine bağlı oluşan osteomiyelit olarak sınıflandırılabilir.

\section{HEMATOJEN OSTEOMIYELIT}

Hematojenöz osteomiyelit, genellikle çocukluk çağında görülen, patojen mikroorganizmaların sistemik dolaşım ile kemiğe ulaşarak enfeksiyona neden olduğu durumdur. Çocukluk çağında en sık alt ve üst ekstremitenin uzun kemiklerinde, erişkinlerde ise vertebrada tutulum izlenir. Kemiklerin kanlanma özelliklerindeki değişime bağlı olarak; bebeklerde, çocuklarda ve yetişkinlerde enfeksiyon gelişim alanı ve klinik seyirde temel farklılıklar izlenir.
Uzun kemiklerin beslenmesini sağlayan besleyici (nutrisiyen) arter, metafiz boyunca uzanarak büyüme plağına kadar ilerler. Bu arterin terminal dalları büyüme plağı altında loop yaparak, medüller bölgenin venöz drenajını yapan venlerle birleşir ve kanın göllendiği sinüzoidal bir ağ oluşturur. Yeni doğan bebeklerde ise 12.-18. aya kadar, nutrisiyen arterin terminal dalları büyüme plağı içerisinden devam ederek, epifize uzanır ve bu bölgenin kanlanmasına katkıda bulunur. Epifize uzanan bu damarlar eklem kıkırdağı altında loop yaparak, bu alandaki venlerle birleşir. Dolayısıyla çocuklarda büyüme plağı altında izlenen sinüzoidal ağ, bu yaş grubunda eklem kıkırdağı altında izlenir. Bebeklik döneminde büyüme plağını kat eden damarlar nedeniyle, metafizer ve epifizer bölgenin kanlanması ilişkilidir. Metafizer ve epifizer bölgenin kanlanması, $12-18$ ay civarında büyüme plağını geçen bu transfiz damarların kapanması ile birbirinden ayrılır. Erişkinlerde ise büyüme plağının kapanması ile metafizer ve epifizer bölge arasındaki damarsal bağlantı yeniden kurulur. Erişkinlerde de, bebeklik dönemine benzer şekilde, sinüzoidal ağ eklem kıkırdağı altında izlenir (Şekil 1). ${ }^{[17]}$

Çocuklarda büyüme plağı altında, bebek ve erişkinlerde ise eklem kıkırdağı altında izlenen sinüzoidal ağ alanları, kemiğin en çok kanlanan bölgeleridir. Bu alanlarda kan akımı yavaş ve türbülanslıdır. Sinuzoidal damar ağı tek sıralı fenestralı endotelyum ile döşelidir. Endotel hücreleri arasında bulunan açıklıklar kandaki hücresel elementlerin kemik dokuya geçmesine izine verir. ${ }^{[18]}$ Ayrıca bu bölgeler retiküloendotelyal sistem hücrelerinden de fakirdir. ${ }^{[19]}$ Yani bu bölgeler hem mikroorganizmanların kolonizasyonuna elverişli hem de savunma sisteminin zayıf olduğu bölgelerdir. Dolayısıyla hematojen osteomiyelitte en sık bu bölgelerde tutulum izlenir.

Bebekler ve erişkinlerde epifizer bölgede izlenen enfeksiyon, eklem kapsülünü aşarak eklem yüzeyine yayılabilmektedir. Bu durum eklem kıkırdağının ciddi tahribatı ve kalıcı sakatık ile ilişkili olabilen septik veya süpüratif artrit gelişimine yol açabilir. Çocuklarda ise büyüme plağı, epifiz ve metafiz arasında bir bariyer görevi gördüğünden, eklem kapsülü tutulumu veya enfeksiyonun eklem yüzeyine yayılımı daha nadiren izlenir. ${ }^{[17]}$

Erişkinlerde en sık tutulumun izlendiği bir diğer alan olan vertebralarda ise, osteomiyelit gelişiminde omurganın venöz ağ yapısı rol oynar. Vertebraların beslenmesini sağlayan damarlar end-plate çevresinde ince vasküler yapılar olarak sonlanmaktadır. Ayrıca pelvik venöz pleksustaki kapak yapılarının eksikliği nedeniyle geri akımlar oluşmaktadır. Geri akımların da etkisiyle bu küçük çaplı damarlar, uzun kemiklerdeki sinüsoidal ağlara benzer şekilde tıkanıklık ve mikroorganizmaların kolonizasyonu için elverişli ortam oluşmasını sağlar. ${ }^{[20]}$ 


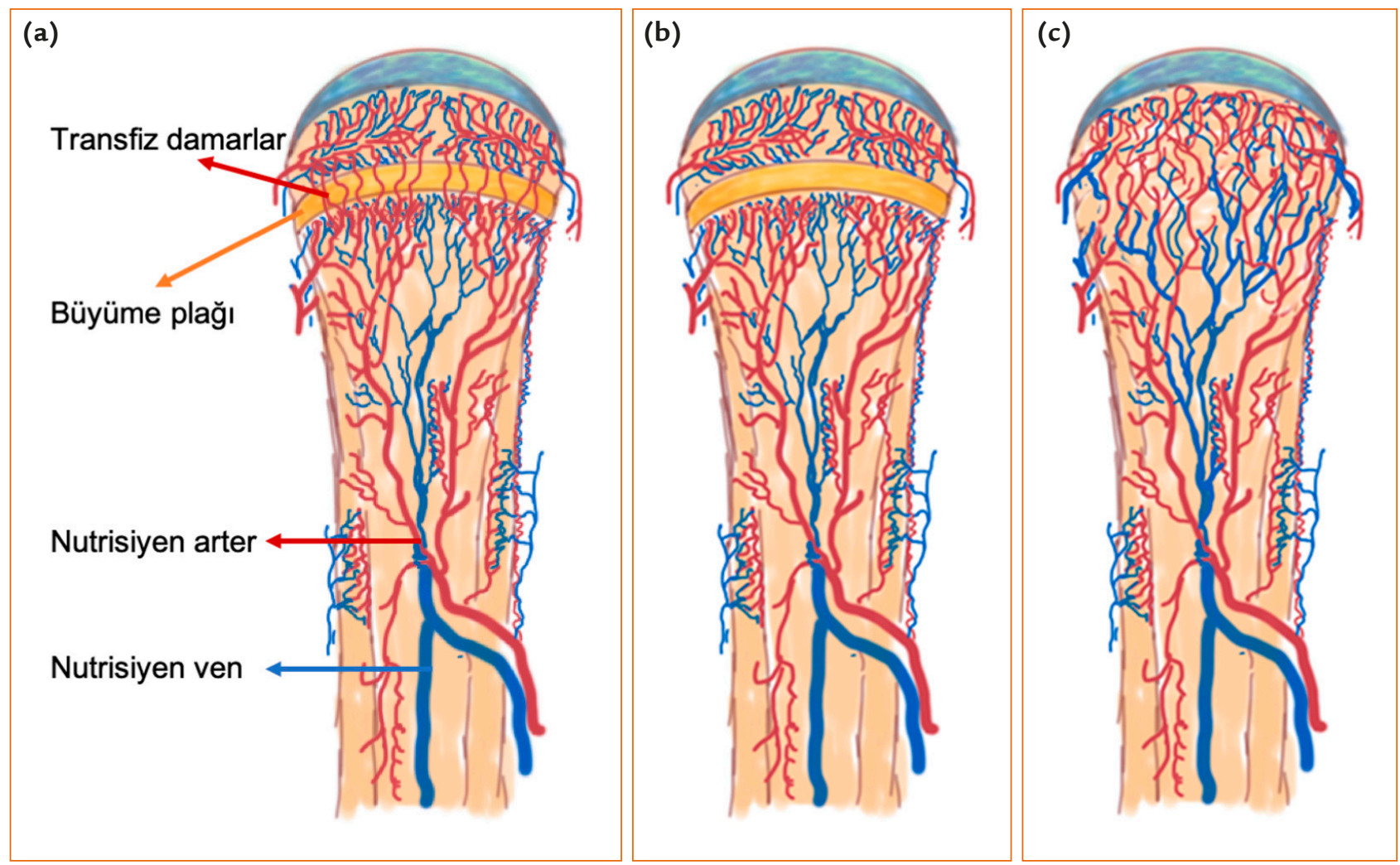

Şekil 1. a-c. Uzun kemik vaskülarizasyonunun şematik çizimi: On sekiz aydan küçük bebeklerde uzun kemik vaskülarizasyonu, büyüme plağını geçen transfiz damarlar nedeniyle metafizer ve epifizer bölgelerin kanlanması ilişkilidir (a). On sekiz ay ile 16 yaş arasındaki çocuklarda uzun kemik vaskülarizasyonu, metafizer ve diyafizer bölgenin kanlanması aynı damar ağı ile sağlanırken, epifizer bölgenin kanlanması ayrı bir damar ağı ile sağlanır. Büyüme plağı, metafizer ve epifizer bölge arasında bariyer görevi görür (b). Erişkinlerde Uzun kemik vaskülarizasyonu, büyüme plağının kapanması ile metafizer ve epifizer bölgelerin kanlanması aynı damar ağı ile sağlanır (c).

Patojen mikroorganizmalar; travma, orak hücre anemisi, pıhtılaşma bozuklukları ve dolaşım yetmezlikleri gibi predispozan durumlarda, sinüzoidal ağlarda oluşan pıhtılar üzerinde kolonize olduktan sonra veya sinuzoidal ağları döşeyen pencereli kapiller yapılardan direkt olarak kemik dokuya geçer. Kemik dokuya geçen mikroorganizmaların retiküloendotelyal sistem hücreleri tarafından tanınması ile dendiritik hücrelerden, IL-1, IL-6 ve tümör nekroz faktör alfa (TNF- $\alpha$ ) salınır. ${ }^{[21]} \mathrm{Bu}$ üç sitokin, akut enflamasyonun temel mediyatörleridir ve enflamasyonun kardinal beş bulgusundan sorumludur. Mediyatörlerin etkisiyle vazodilatasyon ve vasküler geçirgenlikte artış meydana gelir. Artan kan akımı ve basıncın etkisiyle, plazma proteinleri dolaşımdan ayrılarak dokuya geçer. Bunu nötrofiller ve ardından makrofajların dokuya göçü takip eder. Bu aşamada alınacak bir biyopsi örneğinin histopatolojik incelemesinde, proteinöz materyal içerisinde yoğun nötrofilik infiltrasyon, hücre lizisine bağlı nekrotik debris, bunların içerisinde ve çevresinde enflamasyonu sınırlandırmaya çalışan makrofajlar izlenecektir. ${ }^{[21]}$ Klinik olarak ise ateş, ağrı, şişlik, kızarık ve ekstremiteyi hareket ettirme isteğinde azalmadır. Enfeksiyonun direkt grafide saptanabilmesi için en az $1 \mathrm{~cm}$ 'lik alanın etkilenmesi veya kemik mineral içeriğinin \%30-50 azalması gerekmektedir. Erken dönemde bulgular hafif olabileceğinden, direkt grafideki değişiklikler çocuklarda enfeksiyonun başlangıcından 5-7 güne, yetişkinlerde ise 10 ila 14 güne kadar belirgin olmayabilir. ${ }^{[22]}$ Artan kan akımı ve basıncın etkisiyle genişleyemeyen kemik dokunun kan dolaşımı bozulur ve iskemi gelişmeye başlar. Sitokinler ve S.aureus gibi patojen mikroorganizmalardan salınan mediyatörler, osteoblastlarda reseptör aktivator nükleer kappa B ligand (RANKL) üretimini artırır. Osteoblastların dış yüzeyinde bulunan RANKL osteoklastlarda farklılaşmayı uyaran, kemik yıkımına yol açan önemli bir indüksiyon molekülüdür. ${ }^{[23]}$ Ayrıca S.aureus'un sahip olduğu virulans faktörleri, osteoblastik proliferasyonun ve 


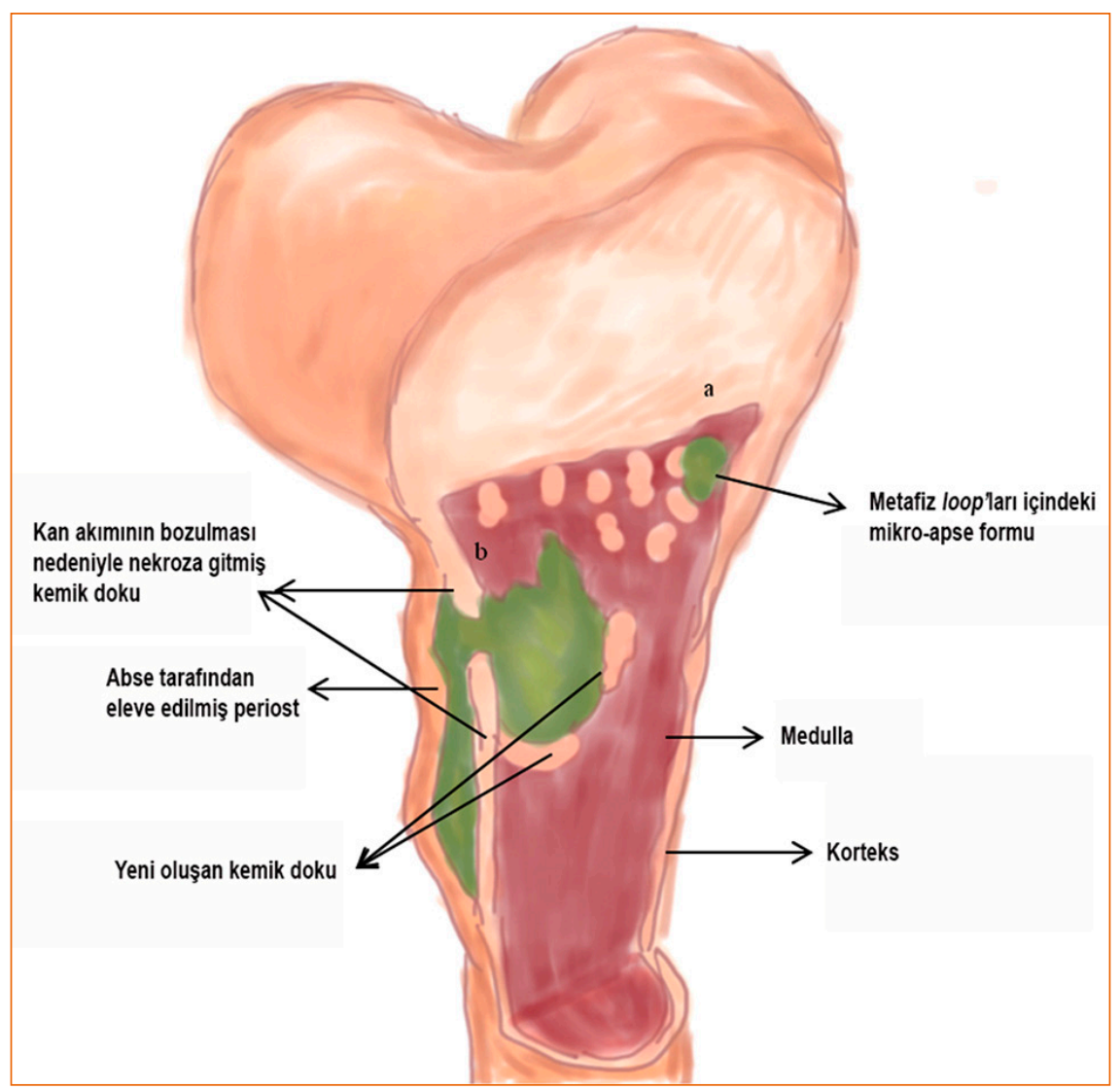

Şekil 2. Akut hematojen hastalıktan, subperiosteal apse, nekrotik kemik ve yeni kemik oluşumu ile karakterize kronik osteomiyelite kadar olan enfeksiyon aşamalarının şematik diyagramı.

diferansiyasyonun durmasına ve kemik mineral kompozisyonunda bozulmalara neden olur ve dahası bu virulans faktörleri osteoblastların apoptoza gitmesinde de rol oynar. Osteoblastik aktivitenin azalması, osteoklastik aktivitenin ise artması nihayetinde kemik yıkımı izlenir. ${ }^{[24]}$

Hastalık bu aşamada kontrol altına alınamaz ise mikroorganizmalar, nötrofiller, makrofajlar, plazma proteinleri ve nekrotik debristen oluşan püy kompakt kemik dokusunu kat ederek periosta kadar ilerler (Şekil 2). Bebekler ve çocuklarda periost kortekse gevşek şekilde bağlıdır. Püy korteks ile periost arasına dolarak, periostu kaldırır ve subperiosteal apse oluşumuna neden olur. Periost ile bağlantısı kaybolan korteksin kan akımı bozulur ve kortekste sekestrum olarak bilinen segmental kemik nekrozu gelişir. Yetişkinlerde ise periost ile korteks arasındaki bağlar daha sıkıdır. Dolayısıyla enflamasyon periostu eleve etmek yerine periostu delerek geçer, yumuşak doku enfeksiyonuna neden olup, cilde ağızlaşabilir.
Sekestrum oluşumu ile hastalık histopatolojik olarak kronik faza geçiş yapmış olur. Kronik aşamada, enfeksiyon alanında makrofajlar, lenfositler ve plazma hücreleri izlenir (Şekil 3a). Bu hücrelerden salınan sitokinler, bakteriyel bileşenler ve toksinler; osteoklastik aktiviteyi daha da artırır. Osteoklastik aktivitenin artması ile nekrotik kemik doku parçalanır ve genişleyen granülasyon dokusuna yer açılır. Fibroblastların aktivasyonu ile kollajen üretiminde artış gerçekleşir ve yeni kan damarlarının oluşumu izlenir (Şekil 3b). Sekestrum etrafindaki medüller boşluk, korteks ve periosteumda yer alan mezenkimal kök hücrelerin uyarılması ile kök hücrelerde osteoblastik diferansiyasyon gerçekleşir ve yeni kemik oluşumu başlar. İnvolukrum olarak da bilinen bu yeni kemik oluşumu ile enfeksiyon alanı sınırlandırılmaya çalışılır. ${ }^{[25]}$ İnvolukrum enfeksiyona karşı sağlıklı kemik doku kadar dirençli değildir. Hastalık bu aşamada kontrol altına alınamaz ise, enfeksiyon yeni kemik oluşumunu aşarak yumuşak doku enfeksiyonuna neden olabilir, cilde ağızlaşabilir. 

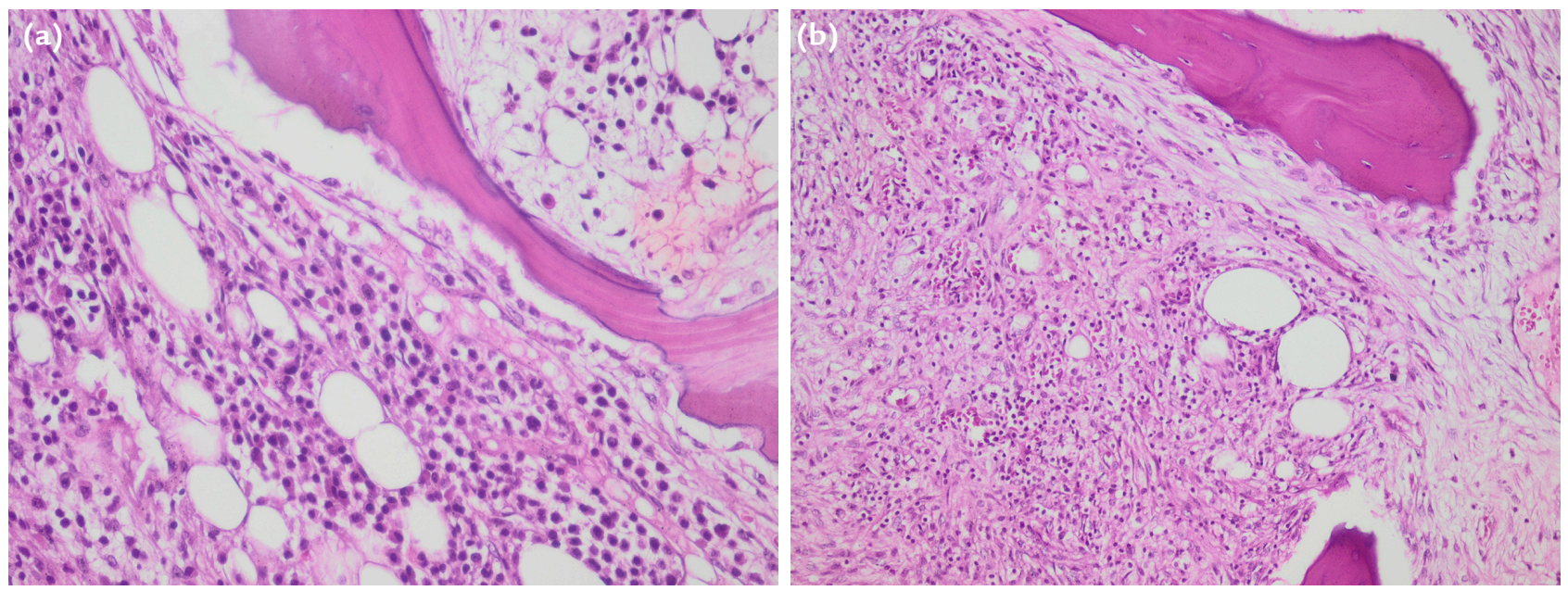

Şekil 3 a, b. İntertrabeküler alanda lenfosit ve plazma hücrelerinden baskın enflamatuar hücre infiltrasyonu (HE×200) (a) ve vasküler proliferasyonun eşlik ettiği fibrozis alanları izlenen kronik osteomiyelit olgusu (HE×100) (b).

Hastalık kontrol altına alınırsa, involukrum yoğunluğu ve kalınlığı giderek artar ve enfeksiyon odağı sınırlandırılır. Enfeksiyon nidüsunun kemik doku ile çevrelenip sınırlandırılması, brodie apsesi olarak tanımlanır. ${ }^{[26]}$ Burada akılda tutulması gereken durum, enfeksiyon odağının tamamen ortadan kaldırılamadığı durumlarda tam bir kürden bahsetmenin olanaksız olduğudur.

Osteomiyelitlerin \%80'inden sorumlu olan S.aureus, cilt ve mukoza başta olmak üzere birçok vücut bölgesinde flora üyesi olarak bulunan, toplumun \%20 -60 'ını asemptomatik olarak kolonize edebilen, çok yönlü bir firsatçı patojendir. S.aureus; toksin salgılama, immun sistem hücrelerinden kaçma, biyofilm, yavaş büyüyen küçük koloni varyantları oluşturma ve antibiyotik direnci geliştirme özellikleri ile hayatı tehdit edici enfeksiyonlara neden olabilir. ${ }^{[27]}$ Bakterilerin kolonizasyonu sonrası gelişen enflamasyon odağı hem konakçı hem de patojen sinyalleri tarafından kontrol edilen dinamik bir süreçtir. İmmun sistem hücreleri bir yandan enfekte doku ve patojenleri bir alanda sınırlandırmaya ve ortadan kaldırmaya çalışırken, diğer yandan çevrelediği mikroorganizmalara koruma sağlamış olur. S.aureus'ların salgıladığı koagülaz enzimi, fibrinojeni fibrine çevirir ve oluşan fibrin ağı bakterilerin etrafını sarar. S.aureus bu fibrin ağı arkasında immun sistem hücrelerinden saklandığı gibi, salgıladıkları panton valentin lökosidin ile polimorfonükleer lökositler (PMNL) ve fagositer hücreler üzerinde porlar açılmasına ve hücre lizisine neden olur. ${ }^{[28]}$ İmmun sistem hücreleri apse merkezine erişemediği için mikroorganizmalar tamamen ortadan kaldırılamaz. Dolayısıyla mikroorganizmalar her ne kadar sınırlandırılmış olsalar da bu alanda canlılıklarını korumaya devam ederler. Uygun şartlar geliştiği takdirde tekrar kolonize olarak hastalık oluşturma riskleri her zaman mevcuttur. Öyle ki 40 yıl sonra bile nüks eden osteomiyelit olguları bildirilmiştir. ${ }^{[29]}$ Bu nedenle kronik osteomiyelitin tedavisinde, enfeksiyon odağının tamamen ortadan kaldırılabilmesi için tüm odakların, yumuşak doku ve kemik iliğinin enfekte doku bırakmayacak şekilde cerrahi debridmanı ve lokal antimikrobiyal ajanlar ile tedavi edilmesi gerekir.

\section{Komşu Enfeksiyon Odağından Bulaşma Yoluyla Gelişen Osteomiyelit}

Erişkinlerde en sık görülen osteomiyelit tipidir. Ülser, derin yumuşak doku apsesi veya septik artirit gibi durumlarda, bitişik alanlardaki enfeksiyon komşuluk yoluyla kemiğe yayılım gösterebilir. En sık metatarslarda ve ayak parmaklarında izlenmekle birlikte, enfeksiyon odağına komşu herhangi bir kemikte karşımıza çıkabilir. En sık karşılaşılan örnekleri, diyabetli hastalarda periferik vasküler hastalık ve periferal nöropatinin katkılarıyla gelişen yüzeyel ülserasyona ve yatalak hastalarda dekubitis ülserlerine sekonder gelişen osteomiyelitlerdir. Yıllar içerisinde diyabet hastalarının yaşam beklentisindeki artış ile ilintili olarak, bu osteomiyelit tipinin görülme sıklığında da artış izlenmiştir. ${ }^{[8]}$

Diyabetli hastalarda vasküker yetmezlik ve periferal nöropatinin katkılarıyla gelişen yüzeyel ülserasyonlar, yumuşak doku enfeksiyonlarına yol açabilir. Bu enfeksiyon alanı başarılı şekilde tedavi edilemez ise, yumuşak dokuları aşan enflamasyon kemik periostuna dayanır. 
Sağlam ve sağlıklı kemik doku enfeksiyona dirençlidir. Ancak bu hastalarda vasküler yetmezlik, koagülopati, ödem ve mikroorganizmaların virulans faktörlerinin de etkisiyle korteksin kanlaması bozulmuş ve enfeksiyonlara karşı direnci azalmıştır. Kanlanması bozulmuş ve savunma sistemi baskılanmış olan kemik doku enflamasyonun yayılmasına karşı, sağlıklı kemik doku kadar karşı koyamaz. Enflamasyon periost yüzeyini aşarsa kortikal kemiğe yayılım gösterir. Enflamasyon daha önce belirtildiği gibi nekroz ve doku harabiyeti oluşturur. Benzer şekilde, enflamasyon sınırlandırılabilirse, nekrotik odaklar yeni kemik oluşumu ile çevrelenir. ${ }^{[25]}$

Hematojen osteomiyelitten farklı olarak, komşuluk yoluyla yayılan osteomiyelitte öncelikle korteks etkilenmektedir. Enfeksiyon odağının özellikleri; tutulum alanını, yayılma hızını ve hastalığın derecesini etkilemektedir. Aynı kemikte birden fazla odakta enfeksiyon izlenebilir. Hatta bu odaklardan birinde akut osteomiyelitin histopatolojik bulguları izlenirken bir diğerinde kronik osteomiyelitin histopatolojik bulguları izlenebilir. Bir diğer önemli husus ise, bu osteomiyelitlerde sıklıkla polimikrobiyal enfeksiyonlar izlenmesidir. ${ }^{[30]}$ Tedavi rejiminde hem aerop hem anaerop bakteriler için uygun antimikrobiyal ajanların kullanılması gerekebilir.

\section{Travma ya da Protez Prosedürleri Sırasında Mikroorganizmaların Doğrudan Kemik İçerisine Ekimiyle Oluşan Osteomiyelit}

Travma sonrası osteomiyelit terimi genellikle açık veya kapalı kırıkların cerrahi tedavisi sonrası gelişen kemik enfeksiyonlarını ifade eder. Travmatik osteomiyelitin patofizyolojisi, dâhil olan kemiklere, yaralanmanın karakteristiğine ve hastanın genel durumuna göre farklılıklar gösterir. Yaralanmanın ciddiyetine ve travmanın şiddetine bağlı olarak değişmekle birlikte, açık kırık olguların \%3-50'sinde, kapalı kırık olgularının ise \%1-5'inde osteomiyelit geliştiği bildirilmiştir. ${ }^{\left[{ }^{[1]}\right.}$ Kapalı kırıklara kıyasla, açık kırıklarda transkutan kontaminasyon riski daha yüksektir.

Kırık sonrası kemik dokuda gelişen pıhtılar ve açık dokular mikroorganizmaların kolonizasyou için elverişli ortam sağlar. Travmanın neden olduğu vasküler dolaşım bozuklukları, kemik bütünlük kaybı ve iskemi de kemik dokunun enfeksiyona karşı direncinde düşmeye neden olur. Kırık hattı ve çevre yumuşak dokular üzerinde kolonize olan mikroorganizmalar enflamasyonu tetikler. Enflamasyon kemik şaftı ve periost yüzeyinde ilerleyerek dokularda hasar ve nekroz gelişimine neden olur. Ayrıca enflamasyon kallus oluşumunu da sekteye uğratır. ${ }^{[25]}$

Ortopedi ve travmatoloji alanında uygulanan ameliyatlarda kırık tespiti için kullanılan plak-vidalar, implantlar ve protez materyalleri ise ayrı bir risk unsurudur.
Çalışmalarda yabancı cisim varlığının enfeksiyona yatkınlığı önemli ölçüde artırdığı gösterilmiştir. Öyle ki deri altı implantlarının çevresindeki S.aureus'un minimal enfekte edici dozunun, implant olmadan ki durumuna göre 100.000 kattan daha düşük olduğu tespit edilmiştir. ${ }^{[32]}$ Kullanılan implantın karakteristik özelliğine, yapısını oluşturan kimyasal özelliklere, maruz kaldığı mikroorganizmaya, mikroorganizmanın virülansına ve konağın enfeksiyona direnç kapasitesine bağlı olarak enfeksiyon gelişim oranlarında değişiklikler izlenebilmektedir. Paslanmaz çelik implantların kullanımında, titanyum implantlara göre enfeksiyon gelişim oranları daha yüksektir. ${ }^{[33]}$ Titanyum implantlar sağlam doku ile sıkı bir bağ oluştururken, paslanmaz çelik implantlarda doku ile implant arasında kapsül vazifesi gören ağsı bir boşluk oluşur. Bu alanda kolonize olan mikroorganizmalar, immun sistem hücrelerinden de saklanarak, kronik enfeksiyonlara neden olabilir. İmplantların yüzey kaplamaları da enfeksiyon gelişiminde önem arz etmektedir. Poli I-lizin-greftli-poli etilen glikol kaplamaların yüzeyine konak fibroblast ve osteoblast hücreleri yapışamadığı ve yayılamadığı için bu kaplamalar kolonizasyona daha dirençlidir. ${ }^{[34]}$

Kemik ile protez arasındaki boşlukları doldurarak stabilizasyonu artıran polimetilmetakrilat ise, kemik ile implant arasında enflamatuvar yanıt aracılığı ile ince fibröz bir doku oluşumuna neden olur. Bu alan mikroorganizmaların kolonizasyonu ve biyofilm oluşumu için oldukça elverişlidir. Dolayısıyla protez sonrası gelişen osteomiyelitler en sık kemik ile sement iç yüzü arasında izlenmektedir. Ayrıca çalışmalarda sementin polarize olmayan formunun, kompleman sistem fonksiyonlarını bozarak fagositik ve lenfositik aktiviteyi de etkilediği gösterilmiştir. ${ }^{[35]}$ Diğer yandan kemik dokudaki hasar nedeniyle vasküler dolaşım bozulduğu için immun sistem hücrelerinin bu alana ulaşımı ve antibiyotiklerin etkinliği de kısıtlı olmaktadır. Protez ve implant yüzeyleri bakterinin kolayca tutunabileceği ve kendisine kompleks bir mikroçevre yaratabileceği, biyofilm tabaka oluşturmasına olanak sağlar. Biyofilm; mikroorganizmaların içine gömülerek birbirlerine veya herhangi bir yüzeye yapışmasını sağlayan, ekstrasellüler polimerik maddeden oluşmuş matriks olarak tanımlanır. Bu yapı canlı dokular ya da cansız cisimlerin yüzeyinde oluşabilir. Biyofilm yapısı, mikroorganizmaların Ph değişikliği gibi olumsuz dış ortam koşullarına, antibiyotik ve dezenfektan maddeler gibi kimyasal ajanlara karşı dayanıklı olmasını sağlar. ${ }^{[36]}$ Biyofilm içerisine gizlenen bakteriler immun sistem hücrelerinden ve fagositozdan korunur. Ayrıca biyofilm matriksi mekanik, fizik ve kimyasal özellikleri ile antibiyotik ve antiseptik gibi bileşiklerin penetrasyonunu azaltarak, kor yapısındaki bakterileri korur. ${ }^{[37]}$ Araştırmalarda, biyofilm içerisindeki mikroorganizmalarının, planktonik formlarına kıyasla 
antibiyotiklere 100-1000 kat, dezenfektan maddelere ise 10-100 kat daha dirençli olabildikleri gözlemlenmiştir. ${ }^{[38,39]}$ Pseudomonas, Enterobacter, Flavobacterium, Alcaligenes, Staphylococcus ve Bacillus'lar biyofilm oluşturabilen bakterilerdendir. ${ }^{[40]}$ Yıllar içerisinde implantların ve protezlerin kullanımındaki artışa paralel olarak biyofilm enfeksiyonlarının görülme sıklığında da artış izlenmiştir. Biyofilm oluşumu, tekrarlayan enfeksiyonlar ve kronik doku hasariyla seyreden pek çok bakteriyel enfeksiyonda önemli etkenlerden birisidir. ${ }^{[38]}$ Mikroorganizmanın planktonik formuna etkili olan antibiyotiğin koruyucu dozunun biyofilmde etkisiz kalması nedeniyle bu enfeksiyonların tedavisi zor ve mortalite riskini yüksektir. ${ }^{[40]}$ Enfeksiyon odağının ortadan kaldırılabilmesi için protez ve implantlar aracılı̆̆ı ile gelişen osteomiyelitlerde, antimikrobiyal tedavilere ek olarak enfekte implantın da çıkarılması gerekebilir.

Özetle, osteomiyelit enfekte olmuş kemiğin yıkım ve nekrozuna yol açan, ilerleyici enflamatuar bir kemik hastalığıdır. Hem kemik dokusunun kendine has özellikleri, hem patojen virulans faktörleri nedeniyle tedavi süreci uzun ve zorludur. Hastalığın gidişatı enfeksiyona neden olan mikroorganizmaya, mikroorganizmaların virülans faktörlerine ve konağın enfeksiyona direnç kapasitesine bağlı olarak değişiklikler göstermektedir. Bunun yanı sıra hastalık tamamen ortadan kaldırılamaz ise nükslerle seyredebildiğinden uzun süreli takip gerektirmektedir. Uygun tedavi planı oluştururken hastanın genel sağlık durumu ve tutulan kemik alanının yanında, enfeksiyona neden olan mikroorganizmayı, virulans faktörlerini ve yayılım şeklini de değerlendirmek gerekir.

\section{KAYNAKLAR}

1. Klenerman L. A history of osteomyelitis from the Journal of Bone and Joint Surgery: 1948 to 2006. J Bone Joint Surg Br 2007;89-B(5):667-70. Crossref

2. Moodie RL. Paleopathology: an introduction to the study of ancient evidences of disease. Urbana, IL: University of Illinois Press; 1923. p. 243-82.

3. Nélaton A. Éléments de Pathologie Chirurgicale, 2'émé ed. Bailliere G, editeur. Paris: 1868. p. 586, 595-7.

4. Orr HW. The treatment of acute osteomyelitis by drainage and rest. 1927. Clin Orthop Relat Res 2006;451:4-9. Crossref

5. Wilkinson FR. Acute haematogenous osteomyelitis. J Bone Joint Surg Br 1951;33-B:6-7. Crossref

6. Arciola CR, An YH, Campoccia D, Donati ME, Montanaro L. Etiology of implant orthopedic infections: a survey on 1027 clinical isolates. Int J Artif Organs 2005;28(11):1091-100. Crossref

7. Calvo C, Núñez E, Camacho M, Clemente D, FernándezCooke E, Alcobendas R, Mayol L, Soler-Palacin P, Oscoz M, Saavedra-Lozano J; Collaborative Group. Epidemiology and Management of Acute, Uncomplicated Septic Arthritis and Osteomyelitis: Spanish Multicenter Study. Pediatr Infect Dis J 2016;35(12):1288-93. Crossref
8. Kremers HM, Nwojo ME, Ransom JE, Wood-Wentz CM, Melton LJ 3rd, Huddleston PM 3rd. Trends in the epidemiology of osteomyelitis: a population-based study, 1969 to 2009. J Bone Joint Surg Am 2015;97(10):837-45. Crossref

9. Museru LM, Mcharo CN. Chronic osteomyelitis: a continuing orthopaedic challenge in developing countries. Int Orthop 2001;25(2):127-31. Crossref

10. Riise OR, Kirkhus E, Handeland KS, Flato B, Reiseter T, Cvancarova M, Nakstad B, Wathne KO. Childhood osteomyelitis-incidence and differentiation from other acute onset musculoskeletal features in a population-based study. BMC Pediatr 2008;8:45. Crossref

11. Gomes D, Pereira M, Bettencourt AF. Osteomyelitis: an overview of antimicrobial therapy. Braz J Pharm Sci 2013;49(1):13-27. Crossref

12. Thakolkaran N, Shetty AK. Acute Hematogenous Osteomyelitis in Children. Ochsner J 2019;19(2):116-22. Crossref

13. Benito $N$, Franco $M$, Coll P, Galvez ML, Jordan M, LopezContreras J, Pomar V, Monllau JC, Mirelis B, Gurgui M. Etiology of surgical site infections after primary total joint arthroplasties. J Orthop Res 2014;32(5):633-7. Crossref

14. Berbari EF, Kanj SS, Kowalski TJ, Darouiche RO, Widmer AF, Schmitt SK, Hendershot EF, Holtom PD, Huddleston PM 3rd, Petermann GW, Osmon DR; Infectious Diseases Society of America. 2015 Infectious Diseases Society of America (IDSA) Clinical Practice Guidelines for the Diagnosis and Treatment of Native Vertebral Osteomyelitis in Adults. Clin Infect Dis 2015;61(6):e26-46. Crossref

15. Neofytos D, Huprikar S, Reboli A, Schuster M, Azie N, Franks B, Horn D. Treatment and outcomes of Candida osteomyelitis: review of 53 cases from the PATH Alliance ${ }^{\circledR}$ registry. Eur J Clin Microbiol Infect Dis 2014;33(1):135-41. Crossref

16. Rosenberg AE, Khurana JS. Osteomyelitis and osteonecrosis. Diagn Histo-pathol 2016;22(10):355-68. Crossref

17. Trueta J. The Three Types of Acute Haematogenous Osteomyelitis. J Bone Joint Surg Br 1959:4;671-80. https:// pdfs.semanticscholar.org/e52f/45036ddded08f38b72a9e48 bc1339d3311a9.pdf

18. Howlett CR, Dickson M, Sheridan AK. The fine structure of the proximal growth plate of the avian tibia: vascular supply. J Anat 1984;139(Pt 1):115-32. https://www.ncbi.nlm.nih. gov/pmc/articles/PMC1164451/

19. Norden CW. Lessons learned from animal models of osteomyelitis. Rev Infect Dis 1988;10(1):103-10. Crossref

20. Wiley AM, Trueta J. The vascular anatomy of the spine and its relationship to pyogenic vertebral osteomyelitis. J Bone Joint Surg Br 1959;41-B(4):796-809. Crossref

21. Rankin JA. Biological mediators of acute inflammation. AACN Clin Issues 2004;15(1):3-17. Crossref

22. Kothari NA, Pelchovitz DJ, MeyerJS. Imaging of musculoskeletal infections. Radiol Clin North Am 2001;39(4):653-71. Crossref

23. Wada $T$, Nakashima $T$, Hiroshi N, Penninger JM. RANKLRANK signaling in osteoclastogenesis and bone disease. Trends Mol Med 2006;12(1):17-25. Crossref

24. Ning RD, Zhang XL, Li QT, Guo XK. The effect of Staphylococcus aureus on apoptosis of cultured human osteoblasts. Orthop Surg 2011;3(3):199-204. Crossref

25. McNally M, Nagarajah K. Osteomyelitis. Orthop Trauma 2010;24(6):416-29. Crossref

26. Brodie BC. An Account of some Cases of Chronic Abscess of the Tibia. Med Chir Trans 1832;17(1):239-49. Crossref 
27. Ricciardi BF, Muthukrishnan G, Masters E, Ninomiya M, Lee CC, Schwarz EM. Staphylococcus aureus Evasion of Host Immunity in the Setting of Prosthetic Joint Infection: Biofilm and Beyond. Curr Rev Musculoskelet Med 2018;11(3):389400. Crossref

28. Bohach GA. Staphylococcus aureus exotoxins. In: Fischetti VA, Novick RP, Feretti JJ, Portnoy DA, editors. Gram-Positive Pathogens, 2nd ed. Washington, DC: ASM Press; 2006. p. 464-77.

29. Waldvogel FA, Vasey $\mathrm{H}$. Osteomyelitis: the past decade. $\mathrm{N}$ Engl J Med 1980;303(7):360-70. Crossref

30. van Asten SA, La Fontaine J, Peters EJG, Bhavan K, Kim PJ, Lavery LA. The microbiome of diabetic foot osteomyelitis. Eur J Clin Microbiol Infect Dis 2016;35(2):293-8. Crossref

31. Trampuz A, Widmer AF. Infections associated with orthopedic implants. Curr Opin Infect Dis 2006;19(4):349-56. Crossref

32. Zimmerli W, Trampuz A, Ochsner PE. Prosthetic-joint infections. N Engl J Med 2004;351(16):1645-54. Crossref

33. Arens S, Schlegel U, Printzen G, Ziegler WJ, Perren SM, Hansis M. Influence of materials for fixation implants on local infection. An experimental study of steel versus titanium DCP in rabbits. J Bone Joint Surg Br 1996;78-B(4):647-51. Crossref
34. Tosatti S, De Paul SM, Askendal A, VandeVondele S, Hubbell JA, Tengvall P, Textor M. Peptide functionalized poly (L-lysine)-g-poly (ethylene glycol) on titanium: resistance to protein adsorption in full heparinized human blood plasma. Biomaterials 2003;24(27):4949-58. Crossref

35. Petty W. The effect of methylmethacrylate on bacterial phagocytosis and killing by human polymorphonuclear leukocytes. J Bone Joint Surg Am 1978;60(6):752-7. Crossref

36. Fleming D, Rumbaugh KP. Approaches to Dispersing Medical Biofilms. Microorganisms 2017;5(2):15. Crossref

37. Stewart PS. Diffusion in biofilms. J Bacteriol 2003;185(5):148591. Crossref

38. Hoiby N, Ciofu O, Johansen HK, Song ZJ, Moser C, Jensen PO, Molin S, Givskov M, Tolker-Nielsen T, Bjarnsholt T. The clinical impact of bacterial biofilms. Int J Oral Sci 2011;3(2):55-65. Crossref

39. Russell AD. Bacterial adaptation and resistance to antiseptics, disinfectants and preservatives is not a new phenomenon. J Hosp Infect 2004;57(2):97-104. Crossref

40. Lynch AS, Robertson GT. Bacterial and fungal biofilm infections. Annu Rev Med 2008;59(1):415-28. Crossref 